\title{
First Report of Polyplax spinulosa in Albino Rats in Banyuwangi, East Java, Indonesia
}

\author{
Widya Ayu Kusuma ${ }^{*}$, Aditya Yudhana ${ }^{2}$, Anita Andriyani', Vivi Oktaviana1, Nadya \\ Amanda Chaerunisa ${ }^{1}$ \\ ${ }^{1}$ Veterinary Student, ${ }^{2}$ Parasitology Department, \\ Faculty of Veterinary Medicine, Universitas Airlangga, \\ UNAIR C-Campus Mulyorejo, Surabaya, Jawa Timur, Indonesia, 60115 \\ *Corresponding author: widya.ayu.kusuma-2015@fkh.unair.ac.id
}

\begin{abstract}
Abstrak
Tikus albino (Rattus norvegicus) merupakan salah satu hewan coba yang sering digunakan oleh peneliti di laboratorium. Tikus albino di laboratorium ditemukan memiliki gejala bulu rontok, bulu kotor, dan gatal pada pangkal ekor dan ditemukan ektoparasit. Departemen Parasitologi PSDKU Universitas Airlangga di Banyuwangi telah mengamati dan mengidentifikasi ektoparasit sebagai penyebab gejala dari tikus tersebut. Tikus albino ini terinfestasi Polyplax spinulosa.
\end{abstract}

Kata kunci: Polyplax spinulosa, Rattus norvegicus, ektoparasit

\begin{abstract}
Albino rats (Rattus norvegicus) is one animal that is often used by researchers in the laboratory. Albino laboratory rats were found to have symptoms of hair loss, the hair is dirty, and itching at the base of the tail and found ectoparasites. Department of Parasitology in Banyuwangi PSDKU Airlangga University have observed and identified ectoparasites as the cause of the symptoms of these rats. Albino rats infested Polyplax spinulosa.
\end{abstract}

Key words: Polyplax spinulosa, Rattus norvegicus, ectoparasites

Received: 15 Mei 2019

\section{INTRODUCTION}

Albino rats are often used as experimental animals in various biomedical studies in the laboratory. Albino rats have a larger size than mice. The physical characteristics of albino rats are small eyes, hairless ears, and tails. Morphological characteristics of albino rats that can be observed are small head and long tail compared to body (Paramita, 2016).

Albino rats as experimental animals often direct contact with humans. It can transmite various zoonotic rodent borne disease. Parasitic infestations are capable of transmit disease to humans (Suroiyah et al., 2018). Many ectoparasites become vectors of various diseases that can transmit diseases between animals as well as between humans (Abdula et al., 2011; Jena et al., 2017; Arifin et al., 2019). There is a possibility that unexpected zoonoses can emerge

from parasites found in peridomestic rats

(Ogunniyi et al., 2014).

Polyplax spinulosa is an ectoparasites louse are cosmopolitan and have a wide distribution throughout the world (Oguniyi et al., 2014). The ectoparasite $P$. spinulosa was found to act as a biological vector of several pathogenic viruses, bacteria, and protozoa that can transmit to humans and transmit disease to laboratory rats that should be free of any disease (Abdula et al., 2011).

According to reports in Indonesia, $P$. spinulosa has been found in house rats in Mataram, West Nusa Tenggara (Tresnani and Suana, 2016), in forest rats and field rats in Sulawesi, Indonesia (Durden, 1987; Durden and Musser, 1991). Currently reports of cases of $P$. spinulosa have not been reported in Java, especially in East Java. The present paper describes the detection of $P$. spinulosa 
infestation at albino rat in Banyuwangi, East Java of Indonesia.

\section{MATERIALS AND METHODS}

At the end of 2017, albino rat with symptoms of hair loss, dirty hair and itching at the base of the tail. Ectoparasites in lesions are found when first observed. Some of these ectoparasites were collected and examined by the PSDKU Parasitology Department of Airlangga University in Banyuwangi. Eight samples were processed and identified natively under a microscope with 100x magnification.
Parasites were identified based on observation of clinical symptoms and lesions in rats and parasitic morphology observervastion under the microscope.

\section{RESULTS AND DISCUSSIONS}

Based on the symptoms that had been observed and indentified by the Parasitology Department of PSDKU Airlangga University in Banyuwangi found that lesions in albino rats caused by $P$. spinulosa.

$P$. spiulosa is an ectoparasite in the form of lice in the order of Phthiraptera and suborder

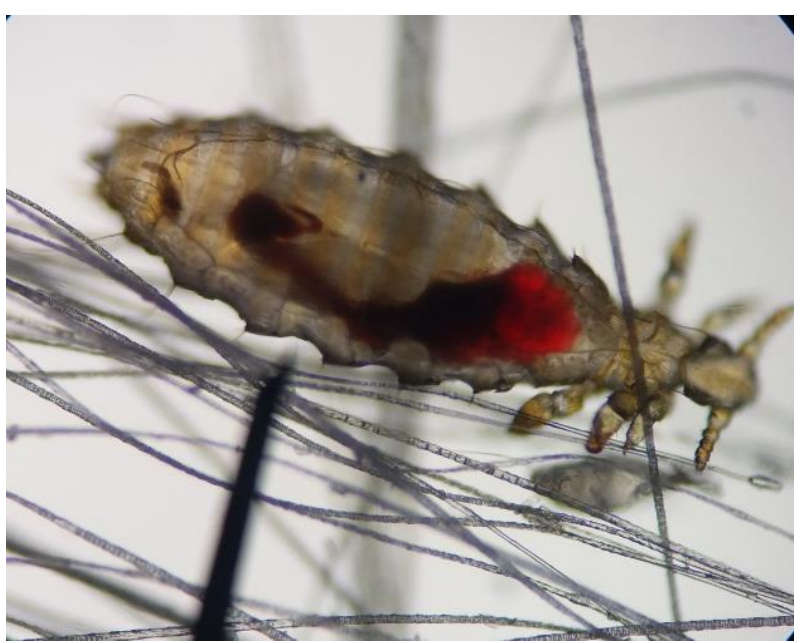

Figure 1. P. spinulosa in observation under a microscope

Anoplura, which is a sucking louse. The characteristic of $P$. spinulosa is a slender body, yellow-brownish in color, this lice has a small head compared to thorax, the antenna has 5 segments, has no eyes, and has a body length of 0.6-1.5 mm (Figure 1). P. spinulosa has a mouth adapted to suck blood from its host. (Hendrick et al., 2016; Suckow et al., 2005).

$P$. spinulosa can be seen directly. It can be observed that the host has eggs, nymphs and adult lice from $P$. spinulosa (Hendrick et al., 2016). These lice lay their eggs on hairs that are close to the skin. The eggs hatch in 5-6 days and become nymphs. Nymphs have paler colors and imperfect reproductive organs. Adult lice can live within 28-35 days. P. spinulosa transmission between animals through direct contact (Suckow et al., 2005).
In the laboratory, infestation of fleas in albino rats is uncommon but can occur accidentally due to contact from other wild animals (Jena et al., 2017). Animals infected with $P$. spinulosa have clinical symptoms that can be observed in the form of scratching, restlessness, weakness, alopecia, pruritus and pale mucous membranes (Hendrick et al., 2016; Jena et al., 2017).

In 2017, P. spinulosa was found in laboratory rat that had the same symptoms. Rats scratching, restlessness, debilitation, alopecia and pallor in the eyes and mucous membranes (Jena et al., 2017). Not only in rats, P. spinulosa has also been reported to be found in Iranian squirrels in 2013. The Iranian squirrel has similar symptoms rats namely alopecia, hair loss and itching of the head and tail (Shirazi et al., 2013). 
P. spinulosa can be a biological vector of pathogenic viruses, bacteria, and protozoa (Abdula et al., 2011). P. spinulosa transmits the disease Haemobartonella muris and Rickettsia typhi between rats (Hendrick et al., 2016).

The sanitation condition of the cage and houses affects the spread of ectoparasites. Lack of attention to cage hygiene accelerates the spread of $P$. spinulosa in one colony. Related to environmental sanitation also influences the spread of wild animals such as wild rats (Abdula et al., 2011).

Treatment that can be used to overcome $P$. spinulosa with insecticides in the form of dust, spray, and dip on both the host and the cage. Ivermectin injection can be used at a dose of $10^{-6}$ $\mathrm{g} / \mathrm{kg}$ subcutaneously (Suckow et al., 2005). Wash using Cis-Cypermethrin can declining the rate of infestation with this ectoparasite (Abdula et al., 2011).

\section{CONCLUSION}

The identification and elimination of parasites remains important because of their impact on animal health. Ectoparasites can act as vectors for the transmission of various bacterial, viral, and protozoan diseases. These parasites can be controlled effectively by preventing the entry of wild rat and filtering animals that enter the laboratory. P. spinulosa does not have direct public health risks, but as an arthropod vector that is capable of transmitting the disease so it needs attention when working with laboratory rat that are full of louse populations.

\section{ACKNOWLEDGMENTS}

Thank you to all supporters of this study. This study was a documentation of the Parasitology Lecturer Assistant during one year tenure.

\section{REFERENCES}

Abdula, A.H., Ahmed, H.S., Aziz, K.K., Ahmed, R.K., Koyee, Q.M. 2011. Infestation Rate With Polyplax Spinulosa (Burmeister, 1839)
Among Certain Laboratory Albino Rats (Rattus Norvegicus) In Relation To Different Washing Agents In Two Erbil City Universities. Zanco J. Med. Sci., 15(1), 4752.

Arifin, K., Kusnoto, Yudhana, A., Sunarso, A., Purnama, M.T.E., Praja, R.N. 2019. Prevalensi Haemonchiasis Pada Kambing Peranakan Etawah di Kecamatan Kalipuro, Banyuwangi. J. Med. Vet., 2(2), 108-111.

Durden, L.A. 1987. The genus Polyplax (Anoplura: Polyplacidae) in Sulawesi, Indonesia, with the description of a new species. Proceedings of the Entomological Society of Washington, 89(4), 811-817.

Durden, L.A., Musser, G.G. 1991. A new species of sucking louse (Insecta, Anoplura) from a montane forest rat in central Sulawesi, and a preliminary interpretation of the sucking louse fauna of Sulawesi. American Museum novitates; no. 3008 .

Hendrix, C.M., Robinson, E.D. 2016. Diagnostic Parasitology for Veterinary Technicians. Elsevier Health Sciences. p204.

Oguniyi, T., Balogun, H., Shasanaya, B. 2014. Ectoparasites and endoparasites of peridomestic houserats in Ile-Ife, Nigeria and implication on human health. Iranian J. Parasitol., 9(1), 134-140.

Jena, S., Parthasarathy, S., Chawla, S. 2017. Identification And Morphological Characterisation Of Spiny Rat Louse (Polyplax Spinulosa) From A Laboratory Rat. J. Entomol. Zool. Stud. India, 5(6), 8284.

Paramita, A. 2016. Pengaruh Pemberian Salep Ekstrak Daun Binahong (Anredera Cordifolia (Ten) Steenis) Terhadap Kepadatan Kolagen Tikus Putih (Rattus Norvegicus) Yang Mengalami Luka Bakar. Skripsi. Universitas Airlangga. 
Shirazi, S., Bahadori, F., Mostafaei, T.S., Ronaghi, H. 2013. First report of Polyplax sp. in a Persian squirrel (Scuirus anomalus) in Tabriz, northwest of Iran. Türk. Parazitol. Derg., 37(4), 299.

Suckow, M.A., Stevens, K.A., Franklin, C.L. 2005. The Laboratory Rat. Elsevier Academic Press. p472.
Suroiyah, F.A., Hastutiek, P., Yudhana, A., Sunarso, A., Purnama, M.T.E., Praja, R.N. 2018. Prevalensi Infeksi Toxocara Cati pada Kucing Peliharaan di Kecamatan Banyuwangi. J. Med. Vet., 1(3), 99-104.

Tresnani, G., Hadi, I., Suana, I.W. 2016. Parasites of house rats (Rattus rattus complex) in Mataram, Lombok, Indonesia. J. Vet. Parasitol., 30(1), 35-38. 